\title{
Preliminary Study on the Solanum nigrum L. (Solanaceae) Complex in the Democratic Republic of the Congo
}

\author{
Blaise Bikandu Kapesa, Marc Sosef, Steven Janssens, Timothée Le Péchon, \\ and Félicien Lukoki Luyeye
}

\section{ABSTRACT}

Black nightshade, or the Solanum nigrum complex, includes a number of species that botanists consider problematic due to their morphological resemblance and the high rate of hybridization. As part of the revision of the family Solanaceae for the Flora central Africa, we realized a molecular study of the Solanum nigrum complex in the western part of the Democratic Republic of Congo. A total of 21 samples of this complex were collected and identified using the recent revision by [11]. The DNA of each specimen was extracted and then amplified by PCR for 4 molecular markers: the two nuclear regions waxy and ITS, and the two chloroplastics markers trnL-F and $t r n H-p s b A$. Additional sequences of specimens reliably identified were obtained from GenBank. The combined molecular data set allowed for the identification of two distinct groups. The first we conclude that in the western part of D.R. Congo, two species of the Solanum nigrum complex occur, both showing high morphological variability, while the true Solanum nigrum is absent from that region. The two species are Solanum americanum Mill. and Solanum scabrum Mill. The results confirm the taxonomic decisions of [11]. The generally low resolution in the analyses did not allow to visualize a geographical signal in the variation.

Keywords: Barcoding; DNA; molecular marker; population; Solanum americanum; Solanum scabrum; species complex; systematics; taxonomy.
Published Online: September 06, 2021

ISSN: 2684-5199

DOI: $10.24018 /$ ejbio.2021.2.5.256

\section{B. K. Bikandu}

Department of Biology, Faculty of

Sciences, University of Kinshasa,

Democratic Republic of Congo.

(e-mail: blaisebik ${ }^{\circledR}$ gmail.com)

M. Sosef

Meise Botanic Garden, Meise, Belgium. (e-mail:

marc.sosef ${ }^{\circledR}$ plantentuinmeise.be)

S. Janssens

Meise Botanic Garden, Meise, Belgium. (e-mail:

steven.janssens ${ }^{@}$ plantentuinmeise.be)

T. Le Péchon

Meise Botanic Garden, Meise, Belgium.

(e-mail:

timothee.lepechon

plantentuinmeise.be)

F. L. Lukoki

Department of Biology, Faculty of Sciences, University of Kinshasa, Democratic Republic of Congo.

(e-mail: felicienlukokiluyeye ${ }^{@}$ yahoo.fr)

"Corresponding Author :

\section{INTRODUCTION}

Solanum L. is the genus with most described species (ca. 1400 species) of the Solanaceae [1]. This taxon has a major social and economic importance; it includes several plants cultivated in many countries (that is to say S. tuberosum L., S. lycopersicum L., S. melongena L.).

The infrageneric taxonomy of Solanum has been the subject of numerous treatments based essentially on morphological characters such as the presence or absence of spines [2]-[4]. or star hairs [5]. This proliferation of classifications, often contradictory, has led to a complex taxonomy and a significant inflation in the number of published names (6931 names [6], [7].

Recent taxonomic studies, using molecular characters, have concluded that Solanum is monophyletic [8] with a large number of subclades [42]. Currently, even with the classification DNA, although probably more natural, it does not seem to be stable, which is why 12 or 13 "informal clades"
[9]; [8], [10] have been defined, eight of which occur in the Central African region including the Democratic Republic of Congo, Rwanda and Burundi [7]. [10], [11] distinguish the Morelloide clade which includes the type species of the genus, S. nigrum L. The complex name Solanum nigrum includes a whole series of closely related species that are also called nightshade, they are annual herbs sometimes subshrubs with 30-120 cm height, can be perennial or short-lived, found in many woodlands as well as in rural habitats in temperate or tropical regions. The leaves are alternate, dark green, soft, rather thin and often riddled with insect holes like those of amaranth [12].

The size of the leaves is quite variable, while the shape ranges from lanceolate to rhombic, oval or heart-shaped, with wavy or large-toothed edges. Both surfaces may be hairy or hairless. The petioles are 1-3 cm long with a winged upper part.

The flowers have prominent bright yellow anthers surrounded by greenish to almost white petals, which recur 
with age. The berries are mostly 6-8 $\mathrm{mm}$ in diameter and dull black, purple-black, red or orange in colour [13], [14].

The diversity of this lineage, otherwise known as "Solanum nigrum", remains difficult to understand, as the morphological differences between the taxonomic entities are very small and difficult to distinguish. These difficulties can be attributed to their strong propensity for complex hybridisation and significant polyploidisation [14], [10]. In DRC, the species of the Solanum nigrum complex are annual herbs, sometimes lianascent, spontaneous in ruderal environments, in wastelands and fallow lands. They are also cultivated by local populations for their medicinal, ornamental and food uses. The plants are also used as fodder. The leaves and fruits are sources of dyes. In the Democratic Republic of Congo (DRC) we could identify five species: $S$. americanum Mill, S. memphiticum J.F.Gmel, S. scabrum Mill, S. tarderemotum Bitter and S. villosum Mill [7]. Among these species of the $S$. nigrum complex mentioned above, $S$. scabrum is indigenous to Africa [15]. For the species $S$. scabrum and S. americanum, their uses as native vegetable are recognised by the old people, both species are recognised as native to the DRC.

Phylogenetic studies on the Morelloides [10] have identified four monophyletic clades. The African species of the Solanum nigrum complex belong to the 'Black Morelloide' clade, which comprises about 30 species [11].Despite the existence of taxonomic treatments of the Morelloide clade, phylogenies that have been done in this group are often limited to one specimen per taxon [10], which does not allow verification of the species monophyly. Alternatively, other studies that have included several specimens per species have not included samples from the DRC that is to say [16].

This is extremely important in the context of species that have wide or global distributions, such as species of the Solanum nigrum complex, and which may have significant regional morphological variation. In the framework of this study six objectives are persued,(1) to collect the samples of the spécim of S.nigrum complex taxa collected in the western part of the DRC, (2) realize the standardized description of taxa of $S$. nigrum complexe collected in the western part of DRC, (3) confirm the presence of the different species of the Morelloid clade in the DRC, (4) test the different molecular markers to verify the possibility of using them as DNA barcodes for these species, at different regional or geographical scales, (5) to understand the specific diversity from the molecular analyses associated with the GenBank data to come up with correct identifications of the Solanum nigrum complex in the western part of DRC, (6) to check if there are regional gene pools and then if the molecular data could give a geographical signal.

\section{MAterials AND MethodS}

\section{A. Plant Material and Data Collection}

We sampled our material mainly in the provinces of Kinshasa, Tshopo, Central Kongo, Kwilu and Kwango. In this study, 20 specimens were collected in the western part of the DRC and one sample came from the north-eastern region (Fig. 1).
The collection of samples of the Solanum nigrum complex from the different sites was a challenging task for the discovery of plant species in situ. Each sample and the regions from which the specimens were collected are listed in Table I.

For each of the specimens, pictures were taken in situ; the aerial parts were collected. The collected plants were pressed, mounted in a herbarium and deposited at BR. At the time of collection of each plant, a leaf sample was taken and preserved in silica gel before being used for DNA extractions.

The initial identification of the specimens collected for this study on the basis of their morphology is mainly based on the work done by [11].To confirm the determinations, we also had the opportunity to consult the collections of Paris (P), Brussels (BR) and Kinshasa (IUK).

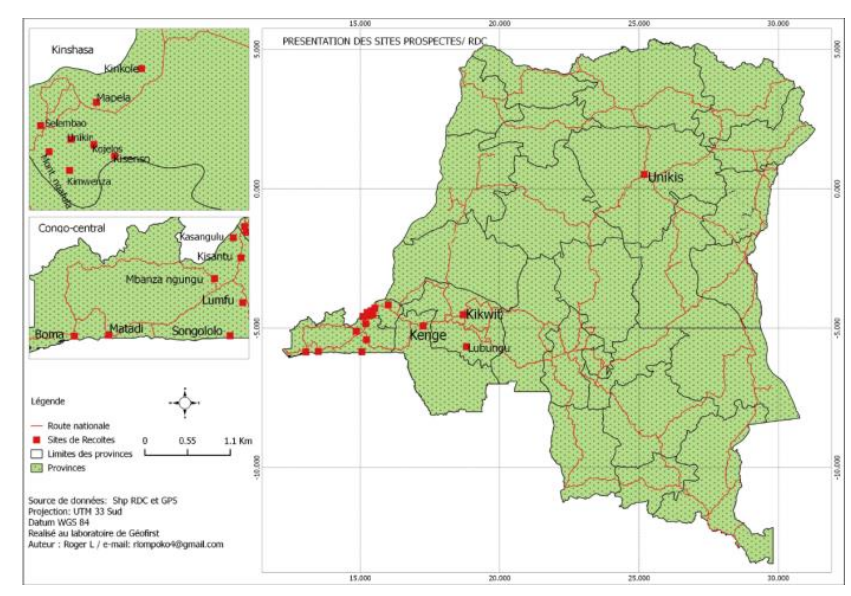

Fig. 1. Harvesting locations for populations of the Solanum nigrum complex.

TABLE I: LIST OF SEQUENCES DOWNLOADED FROM GENBANK

\begin{tabular}{ccccc}
\multicolumn{5}{c}{ FROM GENBANK } \\
\hline Marker & Species & Reference & Accession & Origin \\
\hline GBSSI & S. americanum & {$[10]$} & KT820845 & United \\
GBSSI & S. villosum & {$[33]$} & KC469888 & China \\
GBSSI & S. villosum & {$[33]$} & KC469871 & Unknow \\
GBSSI & S. tarderemotum & {$[10]$} & KT820886 & Costa Rica \\
GBSSI & S. villosum & {$[10]$} & KT820870 & Iran \\
GBSSI & S. villosum & {$[8]$} & DQ169053 & Unknow \\
ITS & S. scabrum & {$[34]$} & JN545016 & South \\
ITS & S. americanum & {$[35]$} & MG219941 & Canada \\
ITS & S. americanum & {$[35]$} & MG220082 & Canada \\
ITS & S. americanum & {$[36]$} & KT891934 & China \\
ITS & S. americanum & {$[36]$} & KT891936 & China \\
ITS & S. americanum & {$[36]$} & KT891935 & China \\
ITS & S. villosum & {$[37]$} & AF244736 & Unknow \\
ITS & S. villosum & {$[18]$} & AY875752 & China \\
trnH- & S. americanum & $[18])$ & AY727179 & Unknow \\
psbA & & & & United \\
trnL-F & S. americanum & {$[10]$} & KT820803 & States \\
trnL-F & S. americanum & {$[38]$} & AY727208 & Unknow \\
trnL-F & S. villosum & {$[39]$} & GU323356 & South \\
trnL-F & S. americanum & {$[40]$} & KP057677 & Unknow \\
trnL-F & S. scabrum & {$[16]$} & GU169330 & Unknow \\
trnL-F & S. villosum & {$[10]$} & KT820839 & Iran \\
trnL-F & S. villosum & {$[41]$} & AY349006 & Unknow \\
trnL-F & S. villosum & {$[41]$} & AY349003 & Unknow \\
trnL-F & S. villosum & {$[41]$} & AY349004 & Unknow \\
trnL-F & S. villosum & {$[41]$} & AY349005 & Unknow \\
trnL-F & S. villosum & {$[41]$} & AY349007 & Unknow \\
trnL-F & S. tarderemotum & {$[10]$} & KT820834 & Kenya \\
trnL-F & S. florulentum & {$[10]$} & KT820811 & Kenya \\
\hline & & & &
\end{tabular}




\section{B. Methods}

\section{1) DNA extraction, amplification and sequence}

Total DNA from dried leaves was extracted using the modified CTAB method [17].

PCR amplifications were performed in a volume of $25 \mu \mathrm{L}$, with $1.6 \mu \mathrm{L} \mathrm{MgCl} 2$, in the presence of $8.7 \mu \mathrm{L}$ water, $2 \mathrm{x}$ buffer, 1.6 $\mu \mathrm{L}$ BSA, $0.1 \mu \mathrm{L}$ dNTP, $0.1 \mu \mathrm{L}$ Taq polymerase, $10.3 \mu \mathrm{L}$ template DNA, for ITS; the master mixes are the same. DNA extraction and amplification was performed at the Laboratory of Molecular Biology of the Botanical Garden of Meise in Belgium.

The genetic markers ITS, waxy, trnL-F and trnH-psbA and the primers two per marker ITS4 and ITS5, trnLc were used for the amplification to have a volume of $0.2 \mu \mathrm{L}$. These chloroplast and nuclear markers were designated for their efficiency and performance from [18] for waxy (GBSSI, 5'GATGGGCTCCAATCAAGAACTAAT-3'), [19] for trnHpsbA, (5'-GTTATGCATGAACGTAATG CTC-3'), [20] for trnL-F (5'-ATTTGAACTGG TGACACGAG-3') and primers by two markers: for ITS4 (5'-TCCTCCGCTTATTGAT ATGC-3') for [21] ITS5 (5'-GAAGTAAAAGTCGTAACA AGG-3'), trnLc (5'-CGAAATCGGTAGACGCTACG-3').

The polymerase chain reaction (PCR) was carried out under the following conditions: an initial denaturation at $94^{\circ} \mathrm{C}$ for 3 min, then 35 cycles comprising (i) denaturation at $94{ }^{\circ} \mathrm{C}$ for $30 \mathrm{~s}$, at $60-50{ }^{\circ} \mathrm{C}$ for $30 \mathrm{~s}$ and at $72^{\circ} \mathrm{C}$ for $1-2 \mathrm{~min}$, (ii) hybridisation or pairing for $3 \mathrm{~h}$, at $45^{\circ} \mathrm{C}$ and then incubation at $4{ }^{\circ} \mathrm{C}$, followed by a final elongation step at $72{ }^{\circ} \mathrm{C}$ for $7 \mathrm{~min}$. After checking that the PCR amplification had a priori worked well, the samples were sent for sequencing to Macrogen Europe. A total of 58 nucleotide sequences from 21 specimens of the Solanum nigrum complex were obtained, including 11 sequences of waxy, 12 sequences of the ITS region, 16 sequences of trnL-F and 19 sequences of the intergenic spacer trnH-psbA. These sequences are all available on GenBank (see Table II).

In order to complete the sampling, we extracted from GenBank another 28 sequences corresponding to five species of the Solanum nigrum complex (Table II). As for our study a correct identification of these samples is very important, and as in the past the taxonomic notion has regularly changed, we made an effort to select only samples with a reliable identification, that is to say. which corresponds to the classification of Särkinen et al. [10], [11].

\section{2) Data analysis}

Geneious v.11.2 software (Biomatters, New Zealand) was used to assemble and correct the complementary sequences. We aligned the resulting sequences using MAFFT [22] using the default parameters. This automatic alignment was manually adjusted in Geneious v.11.2. The selection of the most suitable nucleotide substitution patterns for each of the markers was performed with jModelTest v.2.1.4 [13], [23] and the Akaike information criterion (AIC). GTR+I+G was selected as the most optimal model for trnH-psbA, GTR+G for trnL-F and waxy, and F81+G for ITS. For each of the markers, a phylogenetic tree was reconstructed to check for sustained topological conflict. Each partition (marker) was analysed independently and a concatenation analysis of the matrices of the four molecular markers was also performed.
Kinship relationships were reconstructed by Bayesian inference (BI) using MrBayes v.3.1 software [24]. Each analysis was performed over 10 million generations, with one tree sampled every 1000 generations. The first $25 \%$ of the trees sampled in the analyses were discarded, as they corresponded to the burn-in phase. Chain convergence and ESS parameters were checked with TRACER v.1.4 [25]. The set of selected topologies (i.e,. without the burn-in) was used to reconstruct a majority consensus with each node having a support value corresponding to the Bayesian posterior probability (BPP). On the phylogenetic trees, a node with a BPP value between 0.50 and 0.95 is considered weakly supported. A clade with a BPP value greater than or equal to 0.95 is considered strongly supported [26], [27].

The taxonomic sampling of outgroups is mainly composed of sequences from GenBank. Thus, depending on data availability, topologies were rooted on $S$. americanum for the trnH-psbA marker, on $S$. tuberosum for trnL-F, and on $S$. villosum for waxy and ITS. For the matrix comprising the concatenated data set, S. tuberosum was used as the root because it allows the tree to root well; in addition, $S$. tuberosum is in the same genus as the specimens studied in the $S$. nigrum complex, and allows good reading of the variations in the sequences of specimens studied.

\section{RESULTS \& DISCUSSION}

\section{A. Botanical Data}

We collected 21 specimens of the $S$. nigrum complex in the western part of the DRC, 20 samples in the west and one sample in the northwest. Each specimen collected was made into a herbarium to allow standardized taxonomic description of the species of the S. nigrum complex. The herbarium specimens are deposited at BR with barcode numbers listed in Table II.

On the set of 21 specimens of the $S$. nigrum complex from the DRC, the study on the diagnosis or analysis of botanical characters (habit, stem, leaf, inflorescence, flowers, fruits) allowed the recognition of only two species of the S. nigrum complex: S. scabrum and S. americanum. These species present morphological variations between them. The diagnosis of $S$. americanum and $S$. scabrum was carried out at BR as part of the treatment of the Solanaceae for the Flora of Central Africa (DRC-Rwanda-Burundi). The standardised taxonomic descriptions of two taxa, S. scabrum and $S$. americanum, are given below.

\section{1) S. americanum Mill}

Short-lived annual or perennial herb, up to $1.5 \mathrm{~m}$ high, inerminous; twigs erect or spreading, cylindrical or slightly angular, woody at base, older stems often appearing spinescent, not distinctly hollow; young shoots glabrescent, single-hairy, not glandular, with persistent base. Leaf unremarkable: petiole $(0.3-) 2-4 \mathrm{~cm}$; blade oval to elliptic, $3.5-10.5 \times 1.0-4.5 \mathrm{~cm}$, base attenuated, decurrent on petiole, apex acute, margin entire or sometimes sinuate-dentate, concolorous, membranous, sparsely pubescent with simple, non-glandular hairs above, densely pubescent below; lateral veins 3 to 6 pairs. Inflorescence lateral, simple or rarely bifurcate, umbellate or subumbellate, $0.6-2.5 \mathrm{~cm}(0.4-0.5 \mathrm{in}$.) long, with 3-8 hermaphrodite flowers; stalk (0.5-)1.0-1.8 cm 
(0.4-0.5 in) long. Flower: pedicel 3-9 mm, spreading, straight, hinged at base; calyx bell-shaped, tube $0.8-1.3 \mathrm{~mm}$ long, lobes star-shaped, broadly triangular, 0.3-0.5 mm long, obtuse-topped, sparsely pubescent, not accrescent, lobes strongly reflexed; Corolla star-shaped, 3-6 mm in diameter, white with a yellow-green centre, lobed to $1 / 2-2 / 3$ of the length, with lobes 2.0-3.2 mm long, reflexed at anthesis, pubescent on the back, more densely on the margins and apex; Stamens equal, filaments minutely tubed, $0.5-0.8 \mathrm{~mm}$ free portion, pubescent, anther 0.8-1.5 mm long; ovary globose, glabrous; style 2.2-2.6 mm, exserted for $0.5(-1) \mathrm{mm}$ above anthers, densely pubescent on lower $2 / 3$, stigma capitate. Fruit on straight, spreading pedicel, globose, 4-9 (-12) $\mathrm{mm}$ in diameter, black or purplish-black when ripe, with thin, very shiny pericarp, with $30-50$ seeds, with (0-)2 to 4(-6) stony granules. Seeds weapon-shaped, $1.0-1.5 \times 0.8-1.3 \mathrm{~mm}$, pale yellow [7].

TABLE II: SPECIMENS OF THE SOLANUM NIGRUM COMPLEX COLLECTED IN DRC

\begin{tabular}{|c|c|c|c|c|c|}
\hline $\begin{array}{c}\mathrm{N}^{\circ} \\
\text { HERBIER }\end{array}$ & BAR CODE & SPECIES & CODE & TOWN & PROVINCE \\
\hline Bikandu 1 & $\begin{array}{c}\text { BR00000 } \\
25615999 \mathrm{~V}\end{array}$ & S americanum & M7582 & Kinsenso & Kinshasa \\
\hline Bikandu 2 & $\begin{array}{c}\text { BR00000 } \\
25615937 \mathrm{~V}\end{array}$ & $S$ americanum & M7586 & Unikin & Kinshasa \\
\hline Bikandu 3 & $\begin{array}{c}\text { BR00000 } \\
25616125 \mathrm{~V}\end{array}$ & $S$ americanum & M7593 & Mapela & Kinshasa \\
\hline Bikandu 4 & $\begin{array}{c}\text { BR00000 } \\
25615968 \mathrm{~V}\end{array}$ & $S$ americanum & M7598 & $\begin{array}{l}\text { Mont- } \\
\text { Ngafula }\end{array}$ & Kinshasa \\
\hline Bikandu 5 & $\begin{array}{c}\text { BR00000 } \\
25615906 \mathrm{~V}\end{array}$ & S scabrum & M7600 & Tshiela & $\begin{array}{l}\text { Kongo } \\
\text { central }\end{array}$ \\
\hline Bikandu 6 & $\begin{array}{c}\text { BR00000 } \\
25616064 \mathrm{~V}\end{array}$ & S scabrum & M7605 & $\begin{array}{l}\text { Ndako } \\
\text { pembe }\end{array}$ & Kinshasa \\
\hline Bikandu 7 & $\begin{array}{c}\text { BR00000 } \\
25615920 \mathrm{~V}\end{array}$ & $S$ americanum & M7610 & Kimwenza & Kinshasa \\
\hline Bikandu 8 & $\begin{array}{c}\mathrm{BR} 00000 \\
25616002 \mathrm{~V}\end{array}$ & $S$ americanum & M7616 & Cogelos & Kinshasa \\
\hline Bikandu 9 & $\begin{array}{c}\text { BR00000 } \\
25616026 \mathrm{~V}\end{array}$ & S americanum & M7619 & Selembao & Kinshasa \\
\hline Bikandu 10 & $\begin{array}{c}\text { BR00000 } \\
25616033 \mathrm{~V}\end{array}$ & $S$ americanum & M7624 & Kasangulu & $\begin{array}{l}\text { Kongo } \\
\text { central }\end{array}$ \\
\hline Bikandu 11 & $\begin{array}{c}\text { BR00000 } \\
25616033 \mathrm{~V}\end{array}$ & $S$ americanum & M7629 & Kisantu & $\begin{array}{l}\text { Kongo } \\
\text { central }\end{array}$ \\
\hline Bikandu 12 & $\begin{array}{c}\text { BR00000 } \\
25616088 \mathrm{~V}\end{array}$ & $S$ americanum & M7635 & $\begin{array}{l}\text { Mbanza- } \\
\text { Ngungu }\end{array}$ & $\begin{array}{l}\text { Kongo } \\
\text { central }\end{array}$ \\
\hline Bikandu 13 & $\begin{array}{c}\text { BR00000 } \\
25616101 \mathrm{~V}\end{array}$ & S scabrum & M7644 & Lukala & $\begin{array}{l}\text { Kongo } \\
\text { central }\end{array}$ \\
\hline Bikandu 14 & $\begin{array}{c}\text { BR00000 } \\
25616057 \mathrm{~V}\end{array}$ & S scabrum & M7648 & Songololo & $\begin{array}{l}\text { Kongo } \\
\text { central }\end{array}$ \\
\hline Bikandu 15 & $\begin{array}{c}\text { BR00000 } \\
25615807 \mathrm{~V}\end{array}$ & S scabrum & M7650 & Lemfu & $\begin{array}{l}\text { Kongo } \\
\text { central }\end{array}$ \\
\hline Bikandu 16 & $\begin{array}{c}\text { BR00000 } \\
25615821 \mathrm{~V}\end{array}$ & $S$ americanum & M7655 & Matadi & $\begin{array}{l}\text { Kongo } \\
\text { central }\end{array}$ \\
\hline Bikandu 17 & $\begin{array}{c}\text { BR00000 } \\
25616507 \mathrm{~V}\end{array}$ & S scabrum & M7660 & Kisangani & Tshopo \\
\hline Bikandu 18 & $\begin{array}{c}\text { BR00000 } \\
25615869 \mathrm{~V}\end{array}$ & $S$ americanum & M7668 & Lubungu & Kwilu \\
\hline Bikandu 19 & $\begin{array}{c}\text { BR00000 } \\
25615857 \mathrm{~V}\end{array}$ & $S$ americanum & M7671 & $\begin{array}{l}\text { Sacré } \\
\text { cœur }\end{array}$ & Kwilu \\
\hline Bikandu 20 & $\begin{array}{c}\text { BR00000 } \\
25615982 \mathrm{~V}\end{array}$ & S scabrum & M7679 & $\begin{array}{l}\text { Mboka } \\
\text { mpolo }\end{array}$ & Kinshasa \\
\hline Bikandu 21 & $\begin{array}{c}\text { BR00000 } \\
25615944 \mathrm{~V}\end{array}$ & $S$ americanum & M7681 & N'sele & Kinshasa \\
\hline
\end{tabular}

Morphological variability of $S$. americanum collected in DRC the following pictures (Photo 1, 2,3).

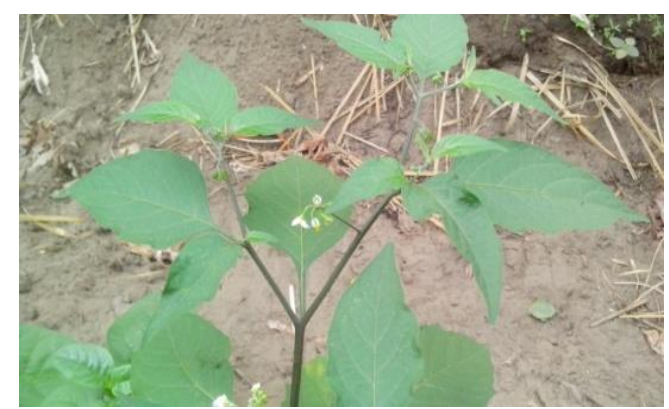

Photo 1. Stem, leaves and flowers of S. americanum in Kinshasa, Unikin

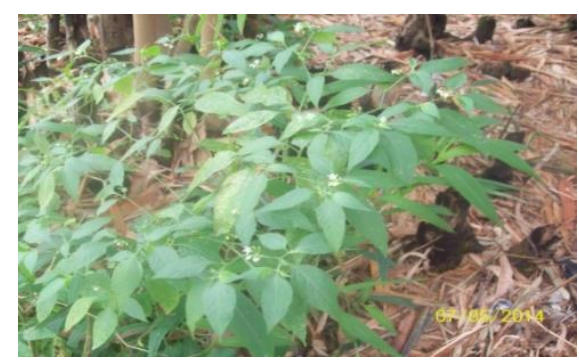

Photo 2. WholePlant with leaves, fruits, flowers of $S$. americanum, Masina

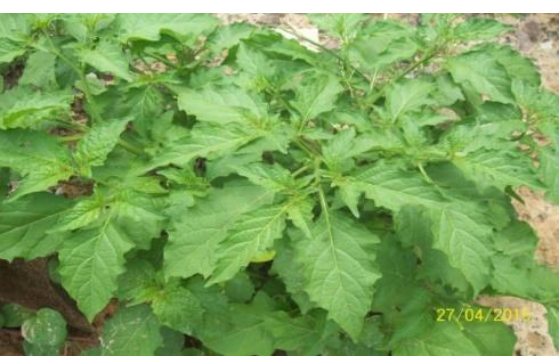

Photo 3. Whole Plant of S. americanum with serrated leaves, Kasangulu

In terms of distribution in the Democratic Republic of Congo, S. americanum has become subspontaneous. A plant of poorly known origin, probably native to America, but widely distributed in tropical and subtropical regions of the world, and in tropical Africa. It is a weed of very common crops (maize and cassava, bananas, gardens), fallows, savannahs, also in tropical montane forest; in Central Africa up to $1800 \mathrm{~m}$ altitude, elsewhere up to $3200 \mathrm{~m}$.

\section{2) S. scabrum Mill}

Perennial or annual herb or creeper, up to $1.5 \mathrm{~m}$ high; stem erect or ascending, often woody at base; twigs spreading, cylindrical, ridged or winged, sometimes spinescent with age, usually somewhat hollow; young shoots with pubescence of simple, spreading, non-glandular hairs. Leaf without remarkable odour; petiole $1-5(-8) \mathrm{cm}$, glabrous to sparsely pubescent; blade broadly ovate to elliptic, 4-15(-20) $\times 3-10(-$ 16) $\mathrm{cm}$, base abruptly contracted or truncate, narrowly decurrent on the petiole, apex rounded to acute, margin entire or rarely superficially lobed, green to dark green to slightly purple above, slightly paler below, both sides glabrous or sparsely pubescent with simple, nonglandular hairs; secondary veins 3 to $6(-8)$ pairs Inflorescence lateral, simple to (cultivated forms) many-branched, 1-2(-4) cm long, subshaped, with 4-10(-30) hermaphroditic flowers per umbel, with glabrous or sparsely pubescent axes; stalk $1-5(-8) \mathrm{cm}$. Flower 5-mother, sometimes 6-or 7-mother in cultivation; pedicel 4-10 mm, straight, spreading, jointed at base; calyx saucer-shaped, tube 0.9-1.1 mm long with slightly unequal, broadly triangular lobes, $0.9-1.5 \times 0.8-1.4$, with rounded apex, green or purple-tinged, glabrous or slightly pubescent, 
margins often scarce and white; Corolla star-shaped, 7-12 $\mathrm{mm}$ (0.4-0.5 in.) across, white to purple-tinged or sometimes lilac to dark purple, with a yellow star in the centre, lobed to $1 / 2$ the length, with spreading or reflexed lobes, 2.5-4 long, densely papery at the apex and margins ; Stamens equal, filaments very short-tubed, the free part $0.5-0.8 \mathrm{~mm}$, glabrous or pubescent, anther 2-3 mm long; ovary globose, glabrous; style $2.5-5 \mathrm{~mm}$, exserted for $0-1.5 \mathrm{~mm}$ beyond the anthers, densely pubescent in the basal $1 / 2$, stigma caput. Fruit on a straight, spreading pedicel, globose to depressed, 10-20 mm in diameter, purplish-black when ripe, the pericarp thick, glossy or somewhat dull, not transparent, with (20-)100-150 seeds, without stony granules; calyx not enlarged, with appressed or spreading to slightly reflexed lobes. Seeds 2$2.8 \times 1.5-1.8 \mathrm{~mm}$, yellow-brown or purple, with a finely warty testa [7]. The different morphological variations of $\mathrm{S}$. scabrum species are shown in (Photo 4-7) represented.

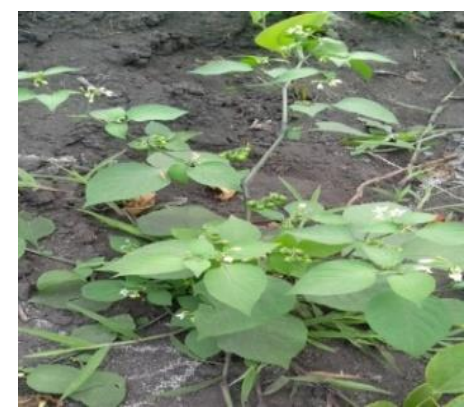

Photo 4. Whole plant, cordate leaves flowers and fruits of $S$. scabrum, Kinshasa

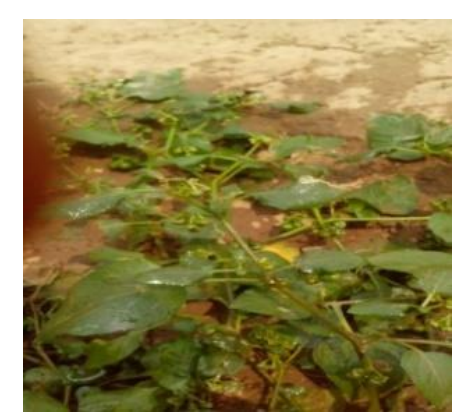

Photo 5. Whole plant with leaves and fruits of S. scabrum Tshiela.

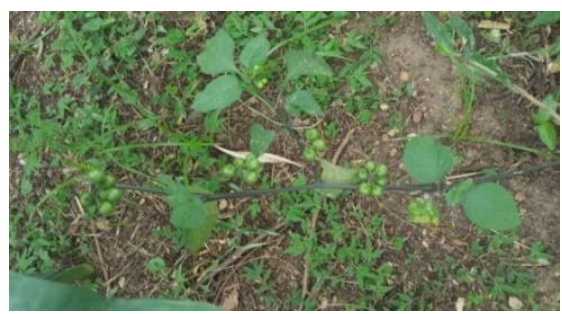

Photo 6. Whole plant with flowers, leaves and fruits of S.scabrum, Kisangani.

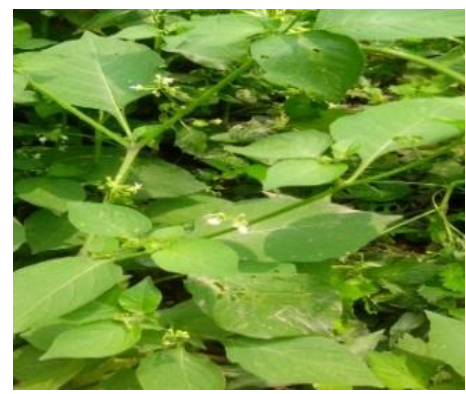

Photo 7. Whole plant with cordate leaves, flowers and fruits of S.scabrum, Tshiela.
S. scabrum is native to Africa but introduced and cultivated almost everywhere in Africa and other parts of the world, it is a ruderal, fallow, wasteland, escaping crop species.

In the Democratic Republic of Congo, the leaves and young shoots are eaten cooked as a vegetable with salt. Contrary to what has been written in old publications, the fruits are not consumed in Africa. The leaves are widely used in traditional medicine, to treat diarrhoea in children as well as certain eye infections and jaundice. In East Africa, the fruit is chewed and swallowed raw to treat stomach ailments. The plants are also used as fodder. The leaves and fruits are sources of dyes. In DRC the plant has the vernacular names kinsumba, ndumbu, nkunga makiadi (in Kikongo language).

\section{B. Molecular Data}

The species of the $S$. nigrum complex are characterised by high morphological variation. In order to better understand the diversity of the species, we considered a study on molecular markers as barcodes that could be used to separate the $S$. nigrum species of the western part of the DRC: the case of $S$. scabrum and S. americanum described above on the morphological level.

Five phylogenetic analyses were performed, one for each of the four molecular markers (i.e., waxy, ITS, trnH-psbA and trnL-F) and one analysis including the concatenated matrix. For waxy, after alignment, the matrix includes 718 characters, of which 67 showed variation, and ten were found to be phylogenetically informative. The analysis distinguishes a weakly supported $\mathrm{A}+\mathrm{B}$ monophyletic group $(\mathrm{BPP}=0.82$; Fig. 4), within which four central African accessions identified as $S$. scabrum are grouped into a weakly supported B monophyletic group (BPP = 0.91; Fig. 2).

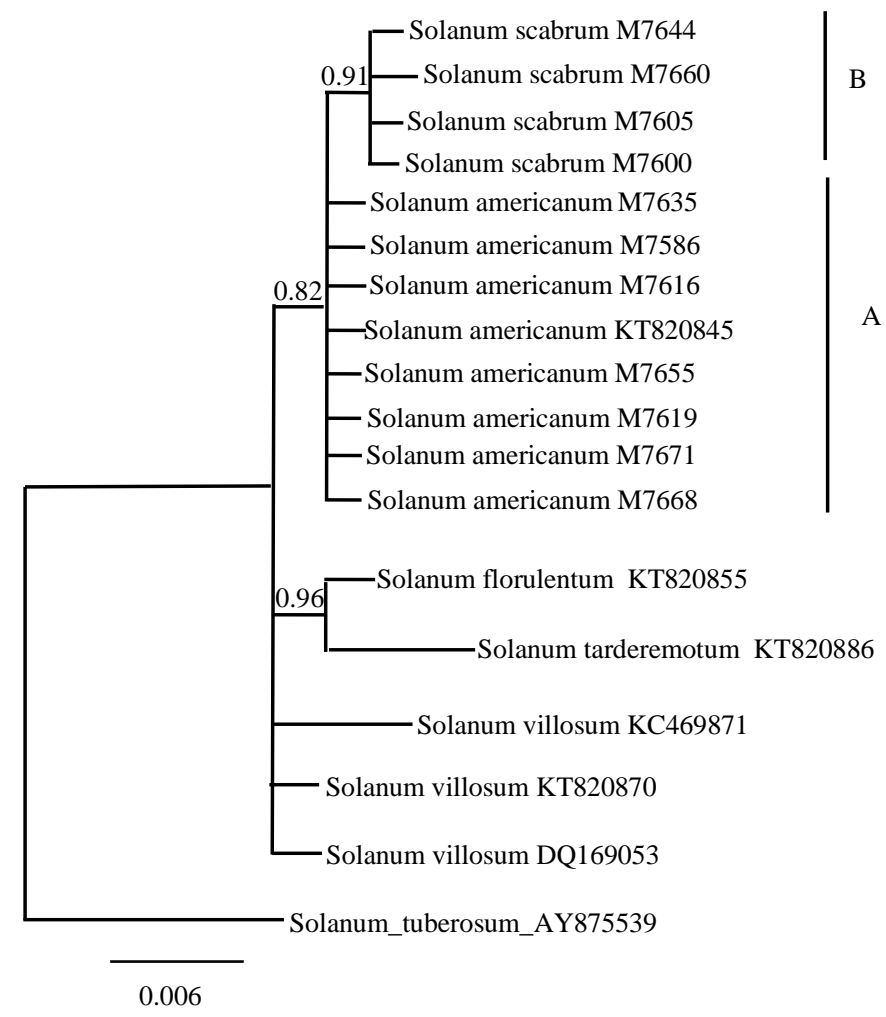

Fig. 2. Phylogenetic reconstruction of the DRC Solanum nigrum complex based on GBSSI nucleotide sequences (waxy). 
The tree from the waxy primer places the four specimens (M7644, M7660, M7605 M7600) identified as S. scabrum (collected in Lukala, Kisangani, Ndako ya pembe, Tshiela) in the same clade (A). These specimens are morphologically identical although collected in completely different locations (Photos). The plants of M7600 resemble those of M7605 in that the leaves are cordate at the base, the stems and fruits are purple. The plants of Tshiela M7600 have cordate leaves but their leaves and stems are green. The same observation is also made for clade B (M7635, M7585, M7616, M7655, M7619, M7671, M7668), these specimens identified as $S$. americanum, and collected in Mbanza Ngungu, Matadi (Central Kongo), Cogelos (Kinshasa), Selembao (Kinshasa), Sacré Coeur and Lubungu (Kikwit-Kwilu) are grouped together. The plants (M7635, M7685, M7616, M7655) showed the same morphology: elliptical, finely lobed leaves. Specimens collected 550 km from Kinshasa (M7671, M7668) grouped together, they have their own morphology as shown in picture 2,3 .

For waxy, we obtained the paraphyletic clade A with $S$. americanum (Fig. 4). In DRC, S. americanum was reported by Särkinen et al [11], although this clade A (with B included) has a BPP $=0.82$, it is weakly supported. As the $S$. americanum sample taken from GenBank (KT820845) is among ours, the presence of S. americanum in the DRC is therefore confirmed. Based on morphological aspects, our specimens identified as $S$. americanum of clade B possess the morphological characters proper to $S$. americanum, such as simple, non-glandular hairs on the stem, a leaf with a whole or sometimes sinuous-dentate, concolorous leaf blade margin, an umbelliform or subombelliform inflorescence and a calyx with strongly reflected lobes. The sequences obtained by waxy can be used as barcodes for species of the S. nigrum complex from the DRC and elsewhere. Samples of $S$. scabrum collected in the DRC have purplish-black fruits, thick, shiny or slightly dull, non-transparent pericarp, with (20-)100-150 seeds, no stony granules and a non-expanded calyx with depressed or spreading to slightly reflexed lobes. These characters are diagnostic for $S$. scabrum according to [11].

After alignment, the molecular array containing the trnHpsbA chloroplast marker sequences includes a total of 364 characters, of which 17 are variable and four informative. The majority consensus generated from this matrix is shown in Fig. 3.

Overall, the topology is largely unresolved. The tree derived from the chloroplast marker trnH-psbA groups $S$. americanum specimens into clade $\mathrm{C}$ and clade $\mathrm{D}$.

Two monophyletic groups are found, clade C and clade D respectively grouping four accessions of $S$. americanum (M7598, M7593, M7582, M7616). These specimens come mainly from Kinshasa (Mont-Ngafula, Mapela, Kinsenso, Cogelos), and are therefore collected from the same site, and all accessions of S. scabrum (M7600, M7644, M7605, M7648, M7660, M7679). However, none of these groups are adequately supported (BPP clade $\mathrm{C}=0.88$; BPP clade $\mathrm{D}=$ 0.78 ), so their monophyly remains questionable. These specimens determined as $S$. scabrum were collected in Lukala (M7644), Ndako pembe (M7605), Songololo (M7648), Kisangani (M7660), Mboka Polo (M7679). The S. scabrum specimens (M7644, M7660, M7605 M7600) grouped together with waxy are also grouped in trnH-psbA, we can recognise clade $\mathrm{C}$, with part of our $S$. americanum samples, and clade D with all our S. scabrum samples (Fig. 3). Neither of these groups is adequately supported (BPP clade $\mathrm{C}=0.88$; BPP clade $D=0.78)$. The only sample obtained from GenBank for this marker (AY727179) and identified as $S$. americanum is clustered among our other $S$. americanum samples outside of clade C. Clade $\mathrm{C}$ groups samples from Kinshasa, but outside of this clade they are also found (M7586, M7610, M7619, M7681), so there is no geographical signal.

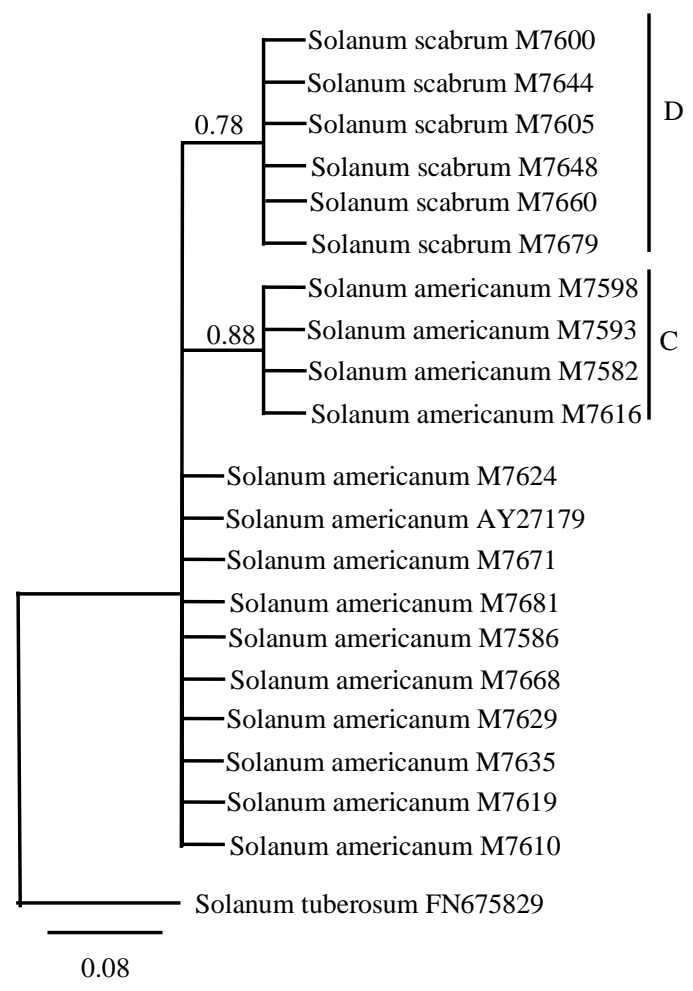

Fig. 3. Phylogenetic reconstruction of the Solanum nigrum complex of the DRC obtained from the nucleotide sequences of trnH-psbA.

The accessions of S. scabrum (M7600, M7644, M7605, M7648, M7660, M7679) studied morphologically are grouped together in the same clade. These specimens determined as S. scabrum were collected in Lukala, Ndako pembe, Songololo, Kisangani, Mboka Mpolo. Specimens that were grouped in the same clade with the waxy marker are also grouped with TrnH-psbA, that is to sayS. scabrum specimens (M7644, M7660, M7605 M7600).

After alignment, the molecular matrix containing ITS sequences includes a total of 600 characters of which 85 are variable and 19 informative. The phylogenetic tree generated from this matrix is presented in Fig. 4.

Clade F accessions; S. scabrum (M7600, JN545016, M7648, M7650, M7644, M7605) and S. villosum (AF244736, KT820910) form a weakly supported clade named $\mathrm{F}(\mathrm{BPP}=0.82)$. Within the F clade, the two specimens identified as S. villosum (AF244736, KT820910) also form a strongly supported monophyletic group $(\mathrm{BPP}=0.98)$. Two other groups are also found, clades E1 (M7616, M7655) and E2 (M7668, M7635, M7671) consisting of two and three accessions of S. americanum respectively (Fig. 4) (with maximum support). 
These S. scabrum specimens (M7644, M7660, M7605 M7600) formed clade A with waxy and with ITS clades D and $\mathrm{C}$, while with trnH- psbA they formed clade D with all six specimens morphologically identified as S. scabrum (M7600, M7644, M7605, M7648, M7660, M7679). Waxy recognised only four specimens as S. scabrum (M7644, M7660, M7605, M7600) and ITS formed clade F with five specimens recognised as S. scabrum (M7600, M7648, M7650, M7644, M7605) together with one specimen from GenBank (JN545016). The trnH-psbA could be a good marker for the recognition of S. scabrum specimens. Three clades, E1, E2 and F, were obtained by ITS (Fig. 4).

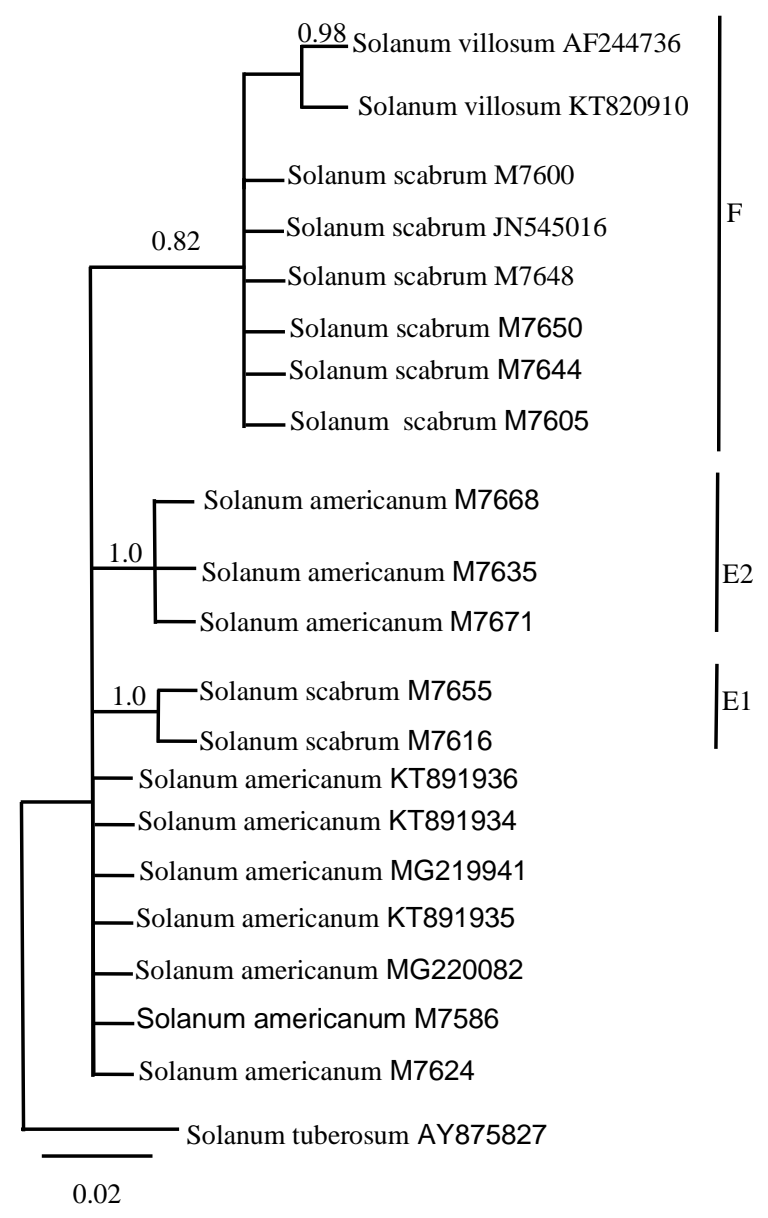

Fig. 4. Phylogenetic reconstruction of the DRC Solanum nigrum complex based on nucleotide sequences by ITS.

Clades E1 and E2 (well supported) include two and three of our $S$. americanum accessions respectively. Clade F, with all our $S$. scabrum samples and two $S$. villosum accessions, is only adequately supported. Among the samples of clade F, we find another sequence extracted from GenBank (JN545016); this confirms the presence of S. scabrum in DRC. With ITS and trnL-F, S. scabrum and S. villosum were placed in a clade, while despite the weak support, they are well separated even if with weak support, as with waxy. This result can be explained by the fact that both species are polyploid [11].

In terms of the geographical distribution of these species, we note that specimens M7585 (Nsele: $50 \mathrm{~km}$ from Unikin), M7616 (Cogelos: $5 \mathrm{~km}$ from Unikin), M7619 (Selembao: 10 $\mathrm{km}$ from Unikin) are all in the same collection area, so it is likely that these specimens constitute the same species $S$. americanum, while specimens M7671 (Sacré cœur), M7668 (Lubungu) were collected in Kikwit, 560 km from Kinshasa, and one specimen from Lubungu was collected in Kinshasa. S.americanum, while specimens M7671 (Sacré cœur), M7668 (Lubungu) were collected in Kikwit, $560 \mathrm{~km}$ from Kinshasa, and a specimen from Matadi (M7655) $365 \mathrm{~km}$ from Unikin. The waxy did group specimens morphologically identified as $S$. americanum.

The molecular matrix containing the trnL-F marker sequences includes, after alignment, a total of 1062 characters, of which 19 are variable and 8 informative. The majority consensus generated from this matrix is presented in Fig. 5.

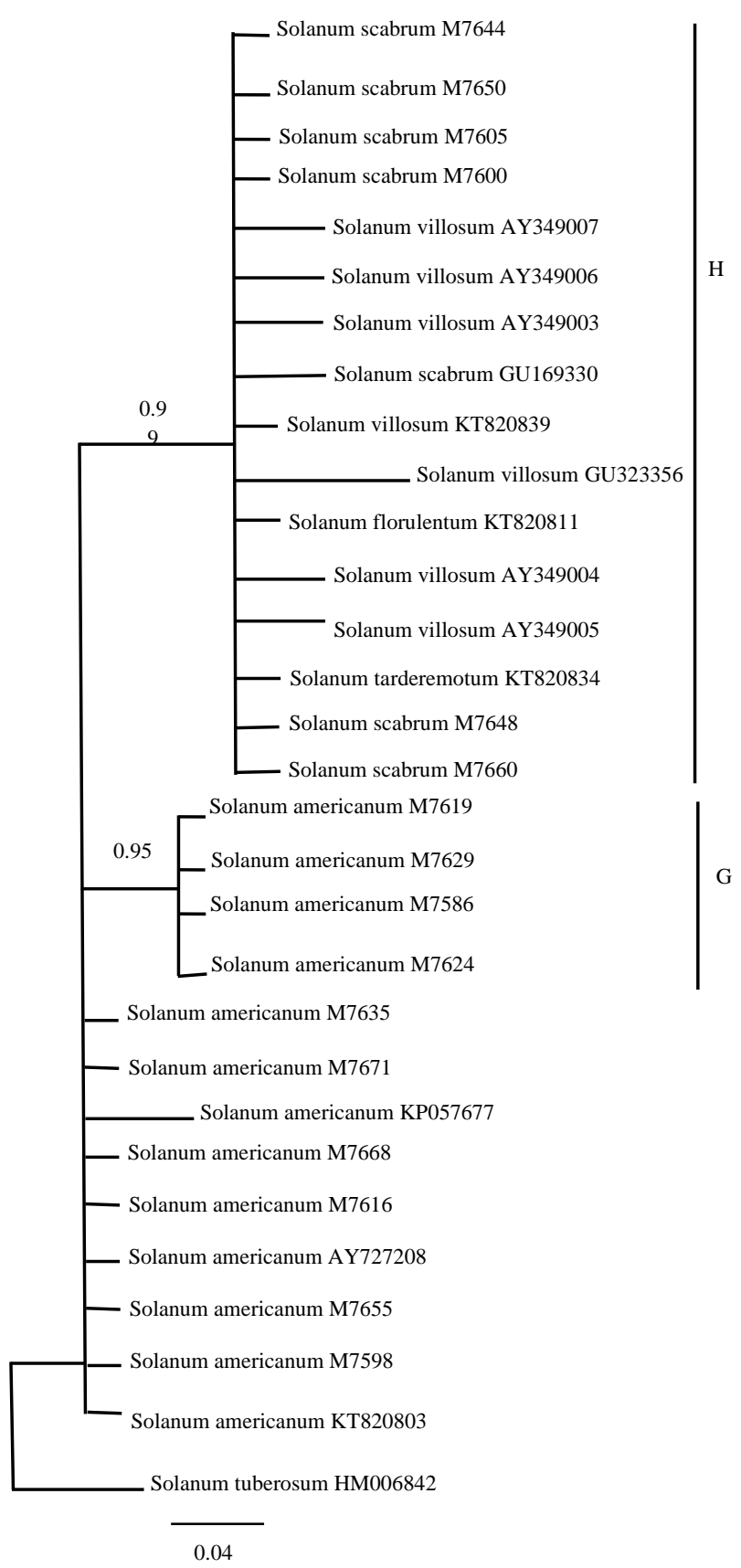

Fig. 5. Phylogenetic reconstruction of the Solanum nigrum complex from the DRC based on trnL-F nucleotide sequences.

On this topology, two clades appear supported. The first noted G (BPP = 0.95) includes four accessions of $S$. americanum (M7619, M7629, M7586, M7624). 
Accessions M7619 (Selembao), M7629 (Kisantu), M7686 (Unikin), M7624 (Kisantu), in clade G are identified as $S$. americanum and all have the same morphology with strongly lobed leaves and are collected in the same geographical area.

A second group noted $\mathrm{H}$ is strongly supported $(\mathrm{BPP}=0.99)$ and includes accessions identified as $S$. tarderemotum (KT820834), S. florulentum (KT820811), S. scabrum (M7644, M7650, M7605, M7600, GU169330, M7648, M7660) and S. villosum (AY349007, AY349006, AY349003, KT820839, GU323356, AY349004, AY349005). The trnL-F marker did group all specimens morphologically determined as S. scabrum. These specimens are true S. scabrum (Fig 3.), as their fruits are purplish black, whereas $S$. villosum has yellow and sometimes red fruits, although both are polyploid species. The trnL-F and trnH-psbA grouped all morphologically determined specimens of S. scabrum (M7600, M7644, M7605, M7648, M7660, M7679). While the waxy recognised only four specimens of S. scabrum. (M7644, M7660, M7605 M7600). For the ITS five of the specimens are grouped as S. scabrum (M7600, M7648, M7650, M7644, M7605). With trnL-F, we obtained the strongly supported clades $\mathrm{G}$ and $\mathrm{H}(\mathrm{BPP}=0.95$ and 0.99 respectively; Fig. 5).

This result further confirms the presence of $S$. americanum in the western part of the DRC based on the presence of the GenBank sample (KT820803) and morphological studies [7].

Our S. scabrum specimens from the DRC are all included in clade H. Furthermore, the fact that accession GU169330 (attached to a specimen identified as S. scabrum) is indeed present within this clade, tends to validate the first morphological results: $S$. scabrum is indeed present in the western part of the DRC [8], [28], [11].

By concatenation and after alignment, the molecular matrix containing the four molecular markers includes a total of 2744 characters of which 188 are variable and 41 informative. The phylogeny reconstructed from this matrix (Fig. 6) generated a cladogram resolved into two clades I and II. His analysis allowed us to obtain only the clades with only the specimens collected in DRC, which helped us to obtain the clades with optimal congruence due to the efficiency of each marker used. The concatenated tree did confirm the results obtained with the analysis of the trees obtained with their marker used independently.

The result of clade I of the concatenated tree demonstrates that all specimens that were determined on the basis of morphological characters are grouped together as shown in Fig. 6.

The result of the concatenated analysis on S. scabrum was already found with some markers such as waxy, trnH-psbA, ITS, trnL-F, although with escape of some specimens. The concatenation only confirmed the previous results for each marker used independently. As indicated above, these $S$. scabrum specimens showed similar morphological characters with elliptical leaves with sinuous teeth, namely specimens M7610 (Kimwenza), M7635 (Mbanza-Ngungu), M7668 (Lubungu in Kikwit), M7671 (Sacré Coeur in Kikwit), M7681 (N'sele) (Fig. 2) are collected in locations totally distant from each other but because of their sequence homology, they group together although showing morphological variations on some character states such as stem and sometimes leaf colour.

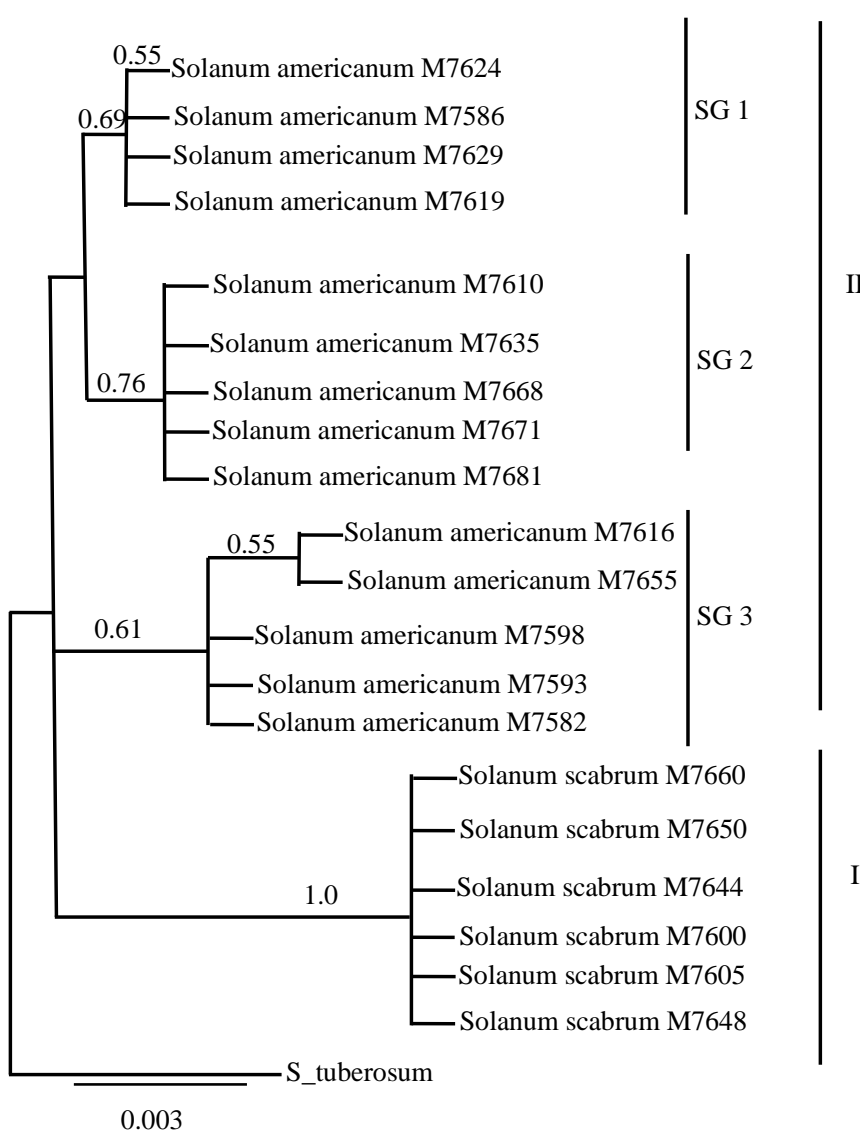

Fig. 6. Majority consensus of the Bayesian analysis of the Solanum nigrum complex of the DRC obtained from the concatenated array of the four molecular markers (GBSSI (waxy), trnL-F, trnH-psbA and ITS).

Clade II consists of three subgroups because they show morphological variability, all of which consist entirely of specimens identified as S. americanum. M7616 (Cogelos), M7655 (Matadi), M7598 (Mont-Ngafula), M7593 (Mapéla), M7582 (Kinsenso) and have elliptical leaves without lobes at the margin and sometimes bearing the acumen.

\section{CONCLUSION AND RECOMMENDATION}

The result of the survey on the complex Solanum nigrum of the West part presents itself as follows:

- The present study used DNA sequences to meet to respond to the main objective, which was to find out if specimens of the Solanum nigrum complex are present in the DRC and if they can be grouped with those of GenBank and finally test the different molecular markers as demonstrated by [10] [11].

- The material was identified with [11] which offers, after a number of extensive studies, the most recent taxonomic concept on this complex. In our study only 21 specimens of the Solanum nigrum complex from the DRC were studied.

- Four molecular markers were used: two chloroplastic (trnL-F, trnH-psbA) and two nuclear (waxy, ITS). From these four markers, nine clades were obtained.

- Finally, the tree obtained from the concatenated matrix of the four molecular markers (Fig. 8) shows that the two species present in the DRC form recognisable entities also at the molecular level, after their morphological identification. 
- At the same time, our molecular approach could also confirm the identifications made on the basis of morphology. In the framework of this study the presence of two species of the S. nigrum complex in the DRC is confirmed.

- Although several of our specimens collected in the DRC showed morphological variations for both $\mathrm{S}$. americanum and $S$. scabrum, from a molecular point of view, the barcodes obtained reveal the presence of two species in the western part of the DRC, namely $S$. americanum and S. scabrum.

- This supports well the taxonomic concept based on morphological characters as proposed recently by [11].With the help of samples extracted from GenBank with a reliable identification, that is to say according to the taxonomic concept of [11], these analyses confirm the presence of $S$. americanum and $S$. scabrum in the western part of the DRC

- Morphological observations and molecular processing show that, among the specimens of the $S$. nigrum complex present in the western part of the DRC, depending on the morphologically and molecularly processed samples, there are two species Solanum nigrum complex: S. americanum and S. scabrum.

- With the help of samples extracted from GenBank with reliable identification [11], these analyses confirm the presence of $S$. americanum and $S$. scabrum in western DRC. The rigour of the taxonomic concept presented by Särkinen et al [11] was also conformed.

- Chloroplastic (trnL-F, trnH-psbA) and nuclear (waxy, ITS) markers did not provide strong trees, and furthermore, our results did not show a geographical signal within the molecular data; but a study based on that is to say microsatellite markers is possible [29]. .

- Environmental and edaphic factors may also be at the basis of the variability observed among the species of the $S$. nigrum complex.

- The sequences obtained can be used as barcodes for the identification of species of the $S$. nigrum complex at the regional level and elsewhere.

\section{ACKNOWLEDGEMENTS}

Our sincere thanks to all the researchers at the Botanical Garden of Meise and to the Central African Flora Project of this institute. This work was funded by the Stichting Arboretum Wespelaar and the International Association of Taxonomy (IAPT). In the course of this study we had valuable input from other solanaceous experts, notably Dr Sandra Knapp (British Museum of Natural History) and Dr Maria Vorontsova (Royal Botanic Gardens, Kew).

\section{REFERENCES}

[1] G.E Barboza., A.T Hunziker., G Bernadello., et al, Solanaceae In: Kadereit J.W. and Bittrich V. (éds) The Families and Genera of Vascular Plants.Springer, Hamburg. XIV: 295-357 2016.

[2] C. Linnaeus. Species plantarum. L. Salvius, Stockholm, 1753.

[3] M.F, Dunal Histoire naturelle, médicale et économique des Solanum et des genres qui ont été confondus avec eux. A. Koenig, Paris, 1813.

[4] M.F, Dunal Solanorum generum que affinium synopsis. Renaud, Montpellier, 1816.
[5] G. Bitter, Solana nova vel minus cognita, XVIII. Repertorium Specierum Novarum Regni Vegetabilis 16: 79-103, 1919.

[6] S. Knapp A revision of the Dulcamaroid Clade of Solanum L. (Solanaceae). PhytoKeys $22: 1-432.2013$.

[7] B. Bikandu, F.Lukoki, J.P.Habari, S.Ntore and M.S.M. Sosef, Solanaceae. In: Sosef M.S.M. (ed.) Flore d'Afrique centrale (Rép. dém. Congo - Rwanda - Burundi), nouvelle série, Spermatophyta. Jardin botanique de Meise, Meise, 2020.

[8] T.L Weese. and L. Bohs, A three-gene phylogeny of the genus Solanum (Solanaceae). Plant Systematics and Evolution 32: 445-463, 2007.https://doi.org/10.1600/036364407781179671.

[9] L. Bohs Major clades in Solanum based on $n d h F$ sequence data. In : Keating R.C., Hallowell V.C. and Croat T. (éds) A festschrift for William G. D'Arcy: the legacy of a taxonomist. Monographs in Systematic Botany from the Missouri Botanical Garden 104, 2005.

[10] T Särkinen., G.E. Barboza and S. Knapp, True black nightshades: phylogeny anddelimitation of the Morelloid clade of Solanum. Taxon 64(5): 945-958, 2015. https://doi.org/10.12705/645.5.

[11] T. Särkinen., P Poczai., G.E Barboza., G.M. Weerden., M. Baden and S. Knapp, A revision of the Old World black nightshades (Morelloid clade of Solanum L., Solanaceae). PhytoKeys 106: 1-223, 2018. https://doi.org/10.3897/phytokeys.106.21991

[12] G. M. Lexa., S. Abel.,H. Budahn., E. Klocke., Characterization of the Solanum Nigrum Complex of Kenya by AFLP Markers. International Journal of Agricultural Science and Technology 3:1, 2017. Inc. doi:10.12783/ijast.2015.0301.02.

[13] E.A., Olet A.K. Lye and M. Heun, Amplified fragment length polymorphisms (AFLPs) analysis of species of Solanum section Solanum (Solanaceae) from Uganda. African Journal of Biotechnology 10(34) : 6387-6395, 2011, https://doi.org/10.5897/AJB10.2494.

[14] J.M. Edmonds and J.A. Chweya, Black nightshades. Solanum nigrum L. and related species. Promoting the conservation and use of underutilized and neglected crops 15. Institute of Plant Genetics and Crop Plant Research and Rome, International Plant Genetic Resources Institute, Gatersleben, 1997.

[15] R.G., Manoko van den Berg R.M.C., Feron van der Weerden G.M. C. and Mariani AFLP markers support separation of Solanum nodiflorum from Solanum americanum sensu stricto (Solanaceae). Plant Systematics and Evolution 267: 1-11, 2007. https://doi.org/10.1007/s00606-007-0531-4.

[16] P. Poczai and J. Hyvönen, Identification and characterization of plastid trnF(GAA) pseudogenes in four species of Solanum (Solanaceae). Biotechnology Letters 33: 2317-2323, 2011, https://doi.org/10.1007/s10529-011-0701-x.

[17] J.J. Doyle and J.L. Doyle, A rapid isolation procedure for small quantities of fresh leaf tissue. Phytochemical Bulletin 19: 11-155, 1987.

[18] D.M Spooner., H Ballard., S.A Stephenson. and Polgar Z, Phylogeny of wild potatoes (Solanum sect. Petota) using the nuclear ITS ribosomal DNA region. University of Wisconsin, Madison,. 2005.

[19] M.B. Hamilton, Four primer pairs for the amplification of chloroplast intergenic regions with intraspecific variation. Molecular Ecology 8 : 521-523, 1999. PMID: 10199016.

[20] P.Taberlet, P.G. Gielly and J Bouvet.. Universal primers for amplication of tree non-coding regions of chloroplast DNA. Plant Molecular Biology 17: 1105-1109, 1991. https://doi.org/10.1007/bf00037152.

[21] White T.J, Bruns T., Lee S. and Taylor J. 1990, Amplification and direct sequencing of fungal ribosomal RNA genes for phylogenetics for phylogenetics. In: Innis M., Gelfand D., Sninsky J. and White T.A (eds) PCR protocole: a guide to methode and application: 315-322. Academic Press, San Diego.

[22] K Katoh, K. Misawa, K. Kuma and T. Miyata MAFFT: a novel method for rapid multiple sequence alignment based on fast Fourier transform. $\begin{array}{lllll}\text { Nucleic Acids } & \text { Reseach } & 30(14): & 3059, .\end{array}$ https://doi.org/10.1093/nar/gkf436.

[23] Posada D.. jModeltest: phylogenetic model averaging, Molecular Biology and Evolution 25(7): 1253-1256, 2008, https://doi.org/10.1093/molbev/msn083.

[24] J.P. Huelsenbeck and F. Ronquist,MRBAYES: Bayesian inference of phylogenetic trees. Bioinformatics 17: 754-755, 2001,https://doi.org/10.1093/bioinformatics/17.8.754.

[25] A.J Drummond. and A Rambaut, BEAST: bayesian evolutionary analysis by sampling tree. BMC Evolutionary Biology 7(1): 214. 2007. https://doi.org/10.1186/1471-2148-7-214

[26] Y Suzuki, G.V. Glasko and M. Nei, Overcredibility of molecular phylogenies obtained by Bayesian phylogenetics. Proceeding of the National Academy of Sciences of the United States of America 99: 16138-16143, 2002, https://doi.org/10.1073/pnas.212646199. 
[27] M.E Alfaro., S. Zoller and F Lutzoni.Bayes or bootstrap? A simulation study comparing performance of bayesian markov chain monte carlo sampling and bootstrapping in assessing phylogenetic confidence. Molecular Biology and Evolution 20(2): 255-266, 2003. https://doi.org/10.1093/molbev/msg028.

[28] P. Latham and Konda ku Mbuta, Plantes utiles du Bas-Congo, République démocratique du Congo, 2005, $2^{\text {me }}$ édition. Mystole Publications, Canterbury.

[29] F.K., Monthe J.Duminil, E Kasongo Yakusu., et al., The African timber tree Entandrophragma congoense (Pierre ex De Wild.) A.Chev. is morphologically and genetically distinct from Entandrophragma angolense (Welw.) C.DC. Tree Genetics and Genomes 14: 66, 2018 https://doi.org/10.1007/s11295-018-1277-6.

[30] M. Renier Flore du Kwango, Tome III. Mission des Jésuites, Kisantu, 1948.

[31] K.M Konda., M., Kabakura B.Mbembe, et al. Plantes médicinales de traditions. Province de l'Equateur - R.D.Congo. Institut de Recherche en Sciences de la Santé, Kinshasa, 2012.

[32] B.F Nzuki.Recherches ethnobotaniques sur les plantes médicinales dans la Région de Mbanza-Ngungu, RDC. Thèse de Doctorat $(\mathrm{PhD})$, Faculté des Sciences en Bio-Ingénierie, Université de Gand, 2016.

[33] W.Zhang, X. Fan, S Zhu., H. Zhao and L. Fu, Species-specific identification from incomplete sampling: applying DNA barcodes to monitoring invasive Solanum plants. PLOS ONE 8(2): e55927,. 2013 https://doi.org/10.1371/journal.pone.0055927.

[34] Viljoen E. and Berger D.K. Morphological and molecular evidence for hybridization and polyploidization in the Solanum nigrum L. complex. Lab. 6-25, 2011, Plant Science, Université de Pretoria.

[35] M.L Kuzmina, T.W.A Braukmann, A.J., Fazekas et al,Using herbarium-derived DNA to assemble a large-scale DNA barcode library for the vascular plants of Canada. Applications in Plant Sciences 5(12): apps.1700079,. 2017, https://doi.org/10.372/apps.1700079.

[36] Y. Wu, B. Wang and L.Xu., Solanaceae DNA molecular identification. University of Traditional Chinese Medicine, 2015.

[37] L. Bohs and R.G. Olmstead, A reassessment of Normania triguera (Solanaceae). Plant Systematics and Evolution 228: 33-48, 2001, https://doi.org/10.1007/s006060170035.

[38] J. Shaw., E.B. Lickey., J.T.,Beck., S.B. Farmer W., Liu., J. Miller, K.C .Siripun., C.T., Winder., D.E.Soltis., R.K., Kuzoff., M.E., Mort., M.Zanis, M. Fishbein, L. Hufford., M. K. Koontz \& Arroyo (2016) Elucidating Deep-Level Phylogenetic Relationships in Saxifragaceae Using Sequences for Six Chloroplastic and Nuclear DNA Regions. Annal.Missouri Botanic. Garden 88(4):669-693.

[39] D.J Oh, K Lee, J.Kim, G.P Son. and Y.-H Jung. Genetic analysis of three Solanum accessions based on nrDNA ITS and trnL-trnF sequences, 2011. Non publié.

[40] C.M Lopes., F De Barba M., Boyer., et al., DNA metabarcoding diet analysis for species with parapatric vs sympatric distribution: a case study on subterranean rodents. Heredity (Edinburgh) 144(5): 525-36, 2014.. https://doi.org/10.1038/hdy.2014.109.

[41] P.W Bosland. and J.B Baral,Phylogenetic analysis of Capsicum using a noncoding region (chloroplast trnL-trnF) of chloroplast. Unpublished thesis. 27-49, 2003. Missouri Botanical Garden, St. Louis.

[42] S.R. Stern., M.F Agra. and L.Bohs. Molecular delimitation of clades within New World species of the "spiny solanums" (Solanum subgenus Leptostemonum). Taxon 60: 1429-1441, 2011.

[43] B.Raoudha., S. Amelb, G. Hassenc and O.B. Azeiz. Extraction de 1'ADN et optimisation de la PCR (Polymorphism Chain Reaction) pour l'application des marqueurs RAPD (Random Amplified Polymorphism DNA) chez Stipa lagascae ,Acta Botanica Gallica, 159:1, 73-78, 2012. DOI: 10.1080/12538078.2012.671646. 